Original Article

\title{
Effect of galactose on proteinuria in pediatric steroid resistant nephrotic syndrome.
}

\author{
Ahmed Hussein Hassan ${ }^{1}$, Ihab Z El-Hakim ${ }^{1}$, Mohammed A Elshenawy ${ }^{2}$ \\ 1- Pediatric department, Ain shams University \\ 2 - Ministry of defense
}

\begin{abstract}
Introduction

Proteinuria in steroid resistant nephrotic syndrome (SRNS) is associated with permeability factor (PF). Galactose has been shown to bind with PF, preventing its interaction with podocyte glycocalyx, and oral administration of galactose may lead to reduction of proteinuria.
\end{abstract}

\section{Aim of the study}

To study the effect of galactose on proteinuria in pediatric patients with steroid-resistant nephrotic syndrome.

Patients and methods

A prospective pilot clinical trial was conducted to investigate the effect of oral galactose on proteinuria in children with SRNS. Seven pediatric subjects with idiopathic SRNS were treated with oral galactose $(0.2 \mathrm{~g} / \mathrm{Kg} / \mathrm{dose}$ twice daily) for 16 weeks.

Monitoring parameters of improvement include clinical; vital signs, weight, absence of edema, frequency of albumin infusion, number of relapse, hospital admission and laboratory; 24 hour urine protein, serum albumin and serum creatinine.

\section{Results}

Study included seven patients, three of them showed clinical and laboratory improvement from the start till the end of therapy. One patient showed only clinical improvement from the start till the end of the therapy. Another patient improved clinically only after 8 weeks and then improved clinically and laboratory after 16 weeks. One patient was late responder (improved clinically and laboratory after 16 weeks) and one did not improve both clinically and laboratory all through the study.

\section{Conclusion}

The addition of galactose to conventional therapy in idiopathic SRNS is associated with clinical \&/or laboratory improvement in most cases. Galactose intake may decrease the need of albumin infusion in resistant cases and hence, need for hospital admission.

Keywords

Steroid resistant nephrotic syndrome, proteinuria, galactose.

Running Title galactose, nephrotic syndrome

\section{Correspondence}

Ahmed Hussein Hassan.

Pediatric department, Children hospital, Ain shams university, Cairo, Egypt.

Email ahmedkhattat@gmail.com

Mobile 01227956737

geget: The Journal of the Egyptian Society of Pediatric Nephrology and Transplantation (ESPNT) geget https://geget.journals.ekb.eg/

Published by ESPNT http://espnt.net/

Cohosted by Egyptian Knowledge Bank https://www.ekb.eg 


\section{Introduction}

The nephrotic syndrome is classically characterized by four clinical features: nephrotic range proteinuria - urinary protein excretion greater than $50 \mathrm{mg} / \mathrm{kg}$ per day, hypoalbuminemia serum albumin concentration less than $3 \mathrm{~g} / \mathrm{dL}$ ( $30 \mathrm{~g} / \mathrm{L})$, edema, and hyperlipidemia [1].

The majority of children who present with idiopathic nephrotic syndrome (NS) have minimal change disease (MCD), which is generally responsive to steroid therapy. As a result, empirical steroid therapy is given to most children who present with idiopathic NS [2]. However, approximately 10 to 20 percent of patients will fail to respond to initial steroid treatment. Most children with steroid-resistant nephrotic syndrome (SRNS), the underlying cause is not known. However, advances in molecular genetics of glomerular diseases have shown single gene defects that affect glomerular podocyte differentiation and function and are responsible for a quarter to a third of all pediatric cases of isolated and syndromic SRNS in many parts of the world [3].

The International Study of Kidney Disease in Children (ISKDC) defined steroid resistant as a minimum exposure of 8 weeks of prednisone with $60 \mathrm{mg} / \mathrm{m}^{2} /$ day; or $2 \mathrm{mg} / \mathrm{kg} /$ day for 4 weeks followed by $40 \mathrm{mg} / \mathrm{m}^{2}$ or $1.5 \mathrm{mg} / \mathrm{kg}$ on alternate days for 4 weeks. The minimum duration of prednisone required to define resistance is unresolved. A kidney biopsy is recommended to evaluate SRNS to determine the underlying pathology, which may dictate therapy.

Idiopathic steroid-resistant nephrotic syndrome (SRNS) in children is characterized by a high risk of progression to endstage renal disease, post-transplant disease recurrence [4] and an overall increased risk of mortality. Approximately $80 \%$ of children with idiopathic SRNS show focal segmental glomerulosclerosis (FSGS) on renal biopsy, whereas the remaining may show minimal change or mesangial proliferation in the early stages. Current therapies for SRNS include cyclosporine, tacrolimus, mycophenolate mofetil and rituximab, may induce partial or complete remission in $25-50 \%$ of children. However, these therapies confer a risk of immunosuppression and nephrotoxicity over time. Thus, there is an urgent need for investigating novel and non-toxic therapies to treat this disease [5].

One or more proteinuria-inducing circulating factors have been identified in children with idiopathic SRNS. This notion is further supported by the rapid recurrence of proteinuria after renal transplant and response to plasmapheresis in some patients. Focal sclerosis permeability factor (FSPF) is one of such circulating factors identified in the serum of patients with idiopathic SRNS and showed that galactose bound to FSPF with high affinity and inactivated and decreased FSPF activity in vitro, but it did not improve proteinuria in a patient with posttransplant FSGS recurrence [5]. The proposed mechanism is the presence of galactose-binding sites on FSPF which interact with galactose of the glomerular glycocalyx to induce proteinuria. Free galactose supplementation may block the FSPF binding sites, thus rendering it inactive and promoting clearance of the FSPF-galactose complex via asialoglycoprotein receptors in the liver. Two case studies subsequently reported complete or partial remission with galactose therapy. Reduced FSPF and complete remission of nephrotic syndrome after oral galactose supplementation was reported in an adult male [6].

\section{Patients and Methods}

The research is a prospective pilot clinical trial. The study was performed on 7 patients between the ages of 2 and 18 years, selected from children's hospital, Nephrology clinic, in our University, collected by simple random sampling. Included patient are those diagnosed as steroid resistant nephrotic syndrome (SRNS), and biopsy proven minimal change, mesangial proliferation or FSGS. Those patients suffer nephrotic range proteinuria despite being on steroids and immunosuppressive therapy. Subjects were given oral galactose at a dose of $0.2 \mathrm{~g} / \mathrm{Kg} /$ dose twice daily (maximum dose $30 \mathrm{~g} /$ day) for a period of 16 weeks. Each dose of galactose (D-Galactose) dissolved in $120 \mathrm{ml}$ of water and ingested every morning and evening for the 16 weeks study period. Other therapies, including steroids and immunosuppressives remained unchanged for the duration of the study. Patients were assessed before starting galactose therapy and after 8 and 16 weeks for the following parameters:

- Clinical: vital signs, weight, and degree of edema, puffiness of eyelids, need of albumin infusion and side effect of drug. Clinical improvement includes weight and absence of edema.

- Laboratory: 24 hour urine protein, serum albumin, and serum creatinine. Laboratory improvement includes serum creatinine, elevated serum albumin and non nephrotic range proteinuria.

Follow up of all responded cases (clinical \&/or laboratory) was done 6 months after stopping galactose intake. An informed consent was obtained from each participant's parents/caregivers after approval by our Research Ethics Committee.

\section{Statistical analysis}

The collected data was revised, coded, tabulated and introduced to a PC using Statistical package for Social Science (SPSS 13.0.1 for windows; SPSS Inc, Chicago, IL, 2001).

\section{Results}

The study included seven patients, all of them had minimal change disease except one focal segmental glomerulosclerosis. Three of them showed clinical and laboratory improvement from the start till end of therapy (Table 1), two minimal change disease and one focal segmental glomerulosclerosis. One patient showed only clinical improvement from the start till the end of the therapy (Table 2). Another patient improved clinically only after 8 weeks and then improved clinically and laboratory after 16 weeks (Table 3). One patient was late responder, improved clinically and laboratory after 16 weeks, (Table4) and one did not improve both clinically and laboratory all through the study (Table 5).

Clinical improvement includes weight and edema, whereas laboratory improvement includes 24 hour urinary protein, serum albumin and serum creatinine. Totally six out of seven studied patients showed improvement (Table 6), five of them had both clinical and laboratory improvement and one had clinical improvement only (Table 7 and figure 1). Four of six responded after 8 weeks of galactose intake and the other two after 16 weeks (Table 8). 
Galactose intake had the advantage of decreasing the need of patients to albumin transfusion, number of relapse and hospital admission. After stoppage of treatment for 6 months (16 weeks), three out of six responded patients maintained on clinical and laboratory remission and the other three suffered from relapse.

Table 1 Clinical and laboratory parameters initially and after 8 and 16 weeks of galactose intake

\begin{tabular}{|c|c|c|c|c|c|}
\hline & & Initial & After 8 weeks & After 16 weeks & Prior therapy \\
\hline \multirow{5}{*}{ Case 1} & S.albumin & $2.2 \mathrm{~g} / \mathrm{dl}$ & $4.5 \mathrm{~g} / \mathrm{dl}$ & $4.7 \mathrm{~g} / \mathrm{dl}$ & \multirow{5}{*}{$\begin{array}{ll}\text { - } & \text { Steroid } \\
\text { - } & \text { Tacrolimus } \\
\text { - } & \text { Mycophenolate } \\
\text { mofetil }\end{array}$} \\
\hline & $\begin{array}{l}\text { Protein in } 24 \mathrm{hrs} \\
\text { urine }\end{array}$ & $2.2 \mathrm{gm} / 24 \mathrm{~h}$ & $0.87 \mathrm{gm} / 24 \mathrm{~h}$ & $0.73 \mathrm{gm} / 24 \mathrm{~h}$ & \\
\hline & S.creatinine & $0.6 \mathrm{mg} / \mathrm{dl}$ & $0.6 \mathrm{mg} / \mathrm{dl}$ & $0.5 \mathrm{mg} / \mathrm{dl}$ & \\
\hline & Weight & $29.5 \mathrm{~kg}$ & $28.5 \mathrm{~kg}$ & $28.5 \mathrm{~kg}$ & \\
\hline & Edema & Present & Absent & Absent & \\
\hline \multirow{5}{*}{ Case 2} & S. albumin & $1.4 \mathrm{~g} / \mathrm{dl}$ & $3 \mathrm{~g} / \mathrm{dl}$ & $3.5 \mathrm{~g} / \mathrm{dl}$ & \multirow{5}{*}{$\begin{array}{ll}\text { - } & \text { Steroid } \\
\text { - } & \text { Tacrolimus } \\
\text { - } & \text { Mycophenolate } \\
& \text { mofetil }\end{array}$} \\
\hline & $\begin{array}{l}\text { Protein in } 24 \mathrm{hrs} \\
\text { urine }\end{array}$ & $3.3 \mathrm{gm} / 24 \mathrm{~h}$ & $1.3 \mathrm{gm} / 24 \mathrm{~h}$ & $0.9 \mathrm{gm} / 24 \mathrm{~h}$ & \\
\hline & S. creatinine & $0.8 \mathrm{mg} / \mathrm{dl}$ & $0.6 \mathrm{mg} / \mathrm{dl}$ & $0.5 \mathrm{mg} / \mathrm{dl}$ & \\
\hline & Weight & $30 \mathrm{~kg}$ & $28 \mathrm{~kg}$ & $28 \mathrm{~kg}$ & \\
\hline & Edema & Present & Absent & Absent & \\
\hline \multirow{5}{*}{ Case 3} & S. albumin & $2.1 \mathrm{~g} / \mathrm{dl}$ & $3.1 \mathrm{~g} / \mathrm{dl}$ & $3.3 \mathrm{~g} / \mathrm{dl}$ & \multirow{5}{*}{$\begin{array}{ll}\text { - } & \text { Steroid } \\
\text { - } & \text { Cyclosporine A } \\
\text { - } & \text { Mycophenolate } \\
\text { mofetil }\end{array}$} \\
\hline & $\begin{array}{l}\text { Protein in } 24 \mathrm{hrs} \\
\text { urine }\end{array}$ & $3.1 \mathrm{gm} / 24 \mathrm{~h}$ & $1.7 \mathrm{gm} / 24 \mathrm{~h}$ & $1.3 \mathrm{gm} / 24 \mathrm{~h}$ & \\
\hline & S. creatinine & $0.7 \mathrm{mg} / \mathrm{dl}$ & $0.5 \mathrm{mg} / \mathrm{dl}$ & $0.6 \mathrm{mg} / \mathrm{dl}$ & \\
\hline & Weight & $45 \mathrm{~kg}$ & $44 \mathrm{~kg}$ & $44 \mathrm{~kg}$ & \\
\hline & Edema & Present & Absent & Absent & \\
\hline
\end{tabular}

Table 2 clinical and laboratory parameters initially and after 8 and 16 weeks of galactose intake

\begin{tabular}{|c|c|c|c|c|}
\hline & Initial & After 8 weeks & After 16 weeks & Prior therapy \\
\hline S. albumin & $1.2 \mathrm{~g} / \mathrm{dl}$ & $2.0 \mathrm{~g} / \mathrm{dl}$ & $2.4 \mathrm{~g} / \mathrm{dl}$ & \multirow{5}{*}{$\begin{array}{l}\text { - Steroid } \\
\text { - Cyclophosphamide } \\
\text { - Mycophenolate mofetil }\end{array}$} \\
\hline Protein in 24 hrs urine & $3.3 \mathrm{gm} / 24 \mathrm{~h}$ & $2.77 \mathrm{gm} / 24 \mathrm{~h}$ & $1.8 \mathrm{gm} / 24 \mathrm{~h}$ & \\
\hline S. creatinine & $0.6 \mathrm{mg} / \mathrm{dl}$ & $0.5 \mathrm{mg} / \mathrm{dl}$ & $0.5 \mathrm{mg} / \mathrm{dl}$ & \\
\hline Weight & $30 \mathrm{~kg}$ & $28 \mathrm{~kg}$ & $28.5 \mathrm{~kg}$ & \\
\hline Edema & Present & Absent & Absent & \\
\hline
\end{tabular}

Table 3 Clinical and laboratory parameters initially and after 8 and 16 weeks of galactose intake

\begin{tabular}{|c|c|c|c|c|}
\hline & Initial & After 8 weeks & After 16 weeks & Prior therapy \\
\hline S. albumin & $1.2 \mathrm{~g} / \mathrm{dl}$ & $2.2 \mathrm{~g} / \mathrm{dl}$ & $3.8 \mathrm{~g} / \mathrm{dl}$ & \multirow{5}{*}{$\begin{array}{ll}\text { - } & \text { Steroid } \\
\text { - } & \text { Cyclophosphamide } \\
\text { - } & \text { Mycophenolate mofetil }\end{array}$} \\
\hline Protein in 24 hrs urine & $3.1 \mathrm{gm} / 24 \mathrm{~h}$ & $1.8 \mathrm{gm} / 24 \mathrm{~h}$ & $0.9 \mathrm{gm} / 24 \mathrm{~h}$ & \\
\hline S. creatinine & $0.8 \mathrm{mg} / \mathrm{dl}$ & $0.5 \mathrm{mg} / \mathrm{dl}$ & $0.6 \mathrm{mg} / \mathrm{dl}$ & \\
\hline Weight & $32 \mathrm{~kg}$ & $31 \mathrm{~kg}$ & $30.5 \mathrm{~kg}$ & \\
\hline Edema & Present & Absent & Absent & \\
\hline
\end{tabular}


Table 4 Clinical and laboratory parameters initially and after 8 and 16 weeks of galactose intake

\begin{tabular}{|c|c|c|c|c|}
\hline & Initial & After 8 weeks & After 16 weeks & Prior therapy \\
\hline S. albumin & $1.9 \mathrm{~g} / \mathrm{dl}$ & $1.5 \mathrm{~g} / \mathrm{dl}$ & $3.1 \mathrm{~g} / \mathrm{dl}$ & \multirow{3}{*}{ Steroid } \\
\cline { 1 - 4 } Protein in 24 hrs urine & $2.4 \mathrm{gm} / 24 \mathrm{~h}$ & $3.1 \mathrm{gm} / 24 \mathrm{~h}$ & $1.2 \mathrm{gm} / 24 \mathrm{~h}$ & $0.5 \mathrm{mg} / \mathrm{dl}$ \\
\cline { 1 - 4 } S. creatinine & $0.6 \mathrm{mg} / \mathrm{dl}$ & $0.7 \mathrm{mg} / \mathrm{dl}$ & $27 \mathrm{~kg}$ & \\
\hline Weight & $30 \mathrm{~kg}$ & $31 \mathrm{~kg}$ & Mbsent & \\
\hline Edema & Present & Present & \\
\hline
\end{tabular}

Table 5 Clinical and laboratory parameters initially and after 8 and 16 weeks of galactose intake

\begin{tabular}{|c|c|c|c|c|}
\hline & Initial & After 8 weeks & After 16 weeks & Prior therapy \\
\hline S. albumin & $2.2 \mathrm{~g} / \mathrm{dl}$ & $1.5 \mathrm{~g} / \mathrm{dl}$ & $1.9 \mathrm{~g} / \mathrm{dl}$ & \multirow{5}{*}{$\begin{array}{ll}\text { - } & \text { Steroid } \\
\text { - } & \text { Mycophenolate mofetil } \\
\text { - } & \text { Cyclosporine A } \\
\text { - } & \text { Tacrolimus }\end{array}$} \\
\hline Protein in 24 hrs urine & $2.3 \mathrm{gm} / 24 \mathrm{~h}$ & $2.7 \mathrm{gm} / 24 \mathrm{~h}$ & $2.5 \mathrm{gm} / 24 \mathrm{~h}$ & \\
\hline S. creatinine & $0.6 \mathrm{mg} / \mathrm{dl}$ & $0.5 \mathrm{mg} / \mathrm{dl}$ & $0.6 \mathrm{mg} / \mathrm{dl}$ & \\
\hline Weight & $25 \mathrm{~kg}$ & $26 \mathrm{~kg}$ & $25 \mathrm{~kg}$ & \\
\hline Edema & Present & Present & Present & \\
\hline
\end{tabular}

Table 6 Distribution of patients according to level of improvement (clinical \pm laboratory).

\begin{tabular}{|c|c|c|c|}
\hline & Improved & Not improved & Total \\
\hline Number & 6 cases & 1 case & 7 cases \\
\hline Percentage & $85.8 \%$ & $14.3 \%$ & $100 \%$ \\
\hline
\end{tabular}

Table 7 Distribution of improved cases according to type of improvement.

\begin{tabular}{|c|c|c|c|}
\hline & Clinical improvement only & $\begin{array}{c}\text { Both laboratory and clinical } \\
\text { improvement }\end{array}$ & Total improved cases \\
\hline Number & 1 case & 5 cases & 6 cases \\
\hline Percentage & $71.6 \%$ & $14.2 \%$ & $85.8 \%$ \\
\hline
\end{tabular}

Table 8 Distribution of improvement timing after intake of galactose ( 8 and16 weeks) both clinical and laboratory remission.

\begin{tabular}{|c|c|c|c|}
\hline & After 8 weeks of therapy & After 16 weeks of therapy & Total improved cases \\
\hline Number & 4 cases & 2 cases & 6 \\
\hline Percentage & $57.2 \%$ & $28.6 \%$ & $85.8 \%$ \\
\hline
\end{tabular}

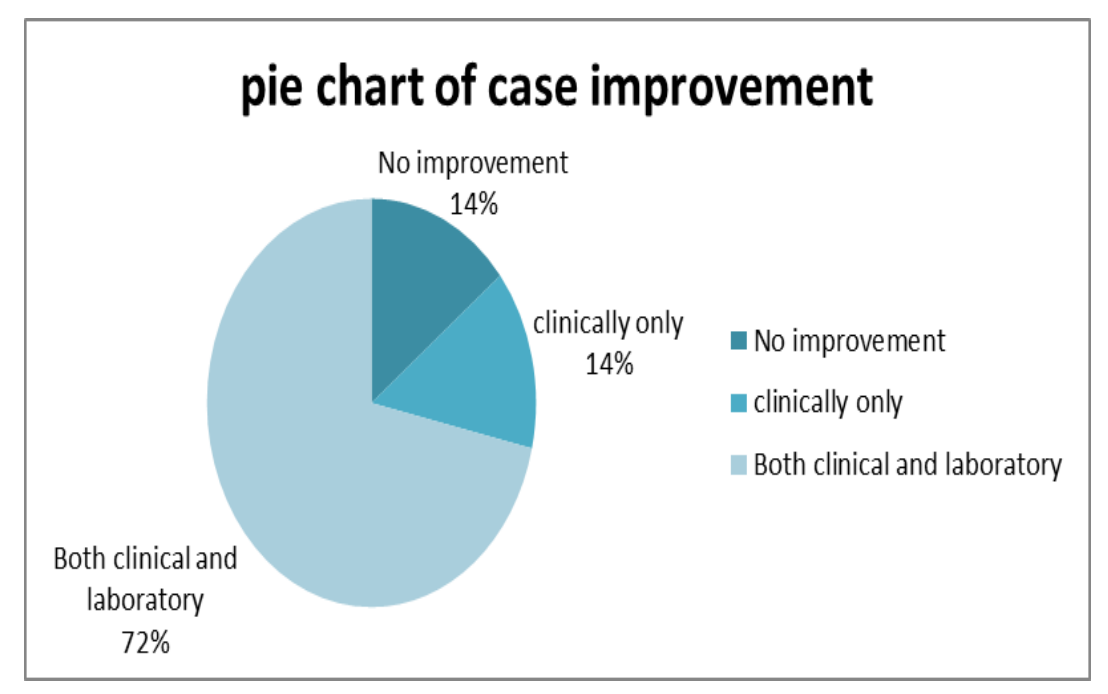

Figure 1 Pie chart denoting the distribution of improvement at the end of the research. 


\section{Discussion}

Studies to show the effect galactose intake in steroid resistant nephrotic pediatric patients are few. In 2013, Sgambat and colleagues studied the effect of galactose on glomerular permeability and proteinuria in steroid resistant nephrotic syndrome. Seven subjects were given oral galactose at a dose of $0.2 \mathrm{~g} / \mathrm{Kg} / \mathrm{dose}$ twice daily (maximum dose $30 \mathrm{~g} / \mathrm{day}$ ) for a period of 16 weeks. Clinical parameters were monitored at baseline (prior to initiation of galactose therapy) and at the 4-, 10- and 16- week time points during galactose therapy. Monitored parameters included morning urine protein: creatinine ratio, serum albumin and serum creatinine. The result was galactose failed to improve proteinuria and serum albumin on all patients, whereas serum creatinine remain unchanged. This disagrees with the results of the current study which showed marked improvement of proteinuria monitored by 24 hour urinary protein and serum albumin done at the start, middle and end of therapy on 5 patients ( 3 patients from the start of therapy till the end, 2 patients after 16 weeks). Serum creatinine remained unchanged during period of study. This might be due to the fact that the current study was done on Caucasians while the study done by Sgambat and colleagues was done on white race.

Focal sclerosis permeability factor (FSPF) is one of such circulating factors identified in the serum of patients with idiopathic SRNS [6] and showed that galactose bound to FSPF has high affinity and inactivated and decreased FSPF activity in vitro, but it did not improve proteinuria in a patient with posttransplant FSGS recurrence. Two case studies subsequently reported complete or partial remission with galactose therapy [7, 8]. Reduced FSPF and complete remission of nephrotic syndrome after oral galactose supplementation was reported in an adult male. Another case report described partial remission during treatment with oral galactose in two pediatric SRNS patients [9]. In the presented study, FSPF activity was not monitored.

\section{Limitation of the study}

Relatively small number of patients being a single center experience so larger population studies are required to verify our findings.

\section{Conclusion}

The addition of galactose to conventional therapy in idiopathic SRNS is associated with clinical \&/or laboratory improvement in most cases. Galactose intake may decrease the need of albumin infusion in resistant cases and hence, need for hospital admission.

\section{References}

1- Mallory L Downie, Gallibois C, Rulan S Parekh and Damien G Noone: Nephrotic syndrome in infants and children: pathophysiology and management. Paediatrics and International Child Health. 2017; 37(4): 248-258.

2- Howard T, Hogan J, and Radhakrishnan J: "Minimal Change." National Kidney Foundation Primer on Kidney Diseases E-Book. 2014; 6: 164-169.

3- Saleem MA and Smoyer WE: "New developments in steroid-resistant nephrotic syndrome." Pediatric Nephrology. 2013; 28(5): 699-709.

4- Sgambat K, Banks $M$ and Moudgil A: "Effect of galactose on glomerular permeability and proteinuria in steroid-resistant nephrotic syndrome." Pediatric Nephrology. 2013; 28(11): 2131-2135.

5- Greenbaum LA, Benndorf $\mathrm{R}$ and Smoyer WE: Childhood nephrotic syndrome-current and future therapies. Nat Rev Nephrol. 2012; 8:445-458.

6- Savin VJ, McCarthy ET, Sharma R, Charba D and Sharma M: Galactose binds to focal segmental glomerulosclerosis permeability factor and inhibits its activity. Transl Res. 2008; 151:288-292.

7- De Smet E1, Rioux JP, Ammann H, Déziel C and Quérin S: FSGS permeability factor-associated nephrotic syndrome: remission after orsl galactose therapy. Nephrology Dialysis Transplantation. 2009; 24(9): 2938-2940.

8- Kopac M, Meglic A and Rus RR. Partial remission of resistant nephrotic syndrome after oral galactose therapy. Therapeutic Apheresis and Dialysis. 2011; 15(3).

9- Mishra OmP, Singh AK, Pohl M, Kumar B, Batra VV and Narayan G. Oral galactose in children with focal and segmental glomerulosclerosis: a novel adjunct therapy. Clin Kidney J. 2014; 7(1): 83-85.

\section{Statements}

\section{Ethics approval and consent to participate}

This study protocol and the consents were approved and deemed sufficient by the Ethical Committee of our institution and informed and written consent was obtained in every case from their legal guardians.

Consents for publication

"Not applicable"

Availability of data and material

"Not applicable"

Conflict of interest

The authors declare no conflict of interest.

\section{Funding}

The authors declare that the research is self-funded by the authors.

\section{Acknowledgements}

Authors would like to thank all patients and their family members for their valuable contributions to the study. 